\title{
Everyday contours and politics of infrastructure: informal governance of electricity access in urban Ghana
}

\author{
Ebenezer F. Amankwaa and Katherine V. Gough
}

Amankwaa, E.F. and Gough, K.V. 2021 Everyday contours and politics of electricity access: informal governance practices in urban Ghana, Urban Studies, 1-21, DOI:

10.1177/00420980211030155

\begin{abstract}
This article contributes to shaping the discourse on unequal geographies of infrastructure and governance in the global South, opening up new ways of thinking through politics, practices and modalities of power. Conceptually, informality, governance, and everyday urbanism are drawn on to unpack how the formal encounters the informal in ways that (re)configure infrastructure geographies and governance practices. This conceptual framing is empirically employed through an analysis of electricity access in Accra, Ghana, highlighting how residents navigate unequal electricity topographies, engage in self-help initiatives, and negotiate informal networks and formal governance practices. The spatiality of the electricity infrastructure has created inequity and opportunities for exploitation by 'power-owners' and 'power-agents' who control and manage the electricity distribution network and, in turn, privately supply power. Electricity connections are negotiated, access is monetized, and illegality excused on grounds of good-neighbourliness, thereby producing and perpetuating everyday politics of 'making do'. Community movements, everyday acts of improvisation, and incremental modifications are shown to influence the workings of formal institutions of government and shape uneven power relations and experiences of inequality. Such an understanding of how marginalised residents navigate the electricity topographies of Accra reveals a more nuanced politics of infrastructure access that reflects the complex realities of hybridized modalities of governance and the multiple everyday dimensions of power that operate to shape urban space. The article concludes that informality should not be recognised as failure but as a sphere of opportunity, innovation and transition.
\end{abstract}

Keywords: Electricity; Informality; Governance; Everyday urbanism; Informal settlement; Abuja; Accra

\section{Introduction}

Urban environments are critical for governance and infrastructure delivery, yet across the global South many urban residents do not have access to reliable, affordable, and inclusive services. For inhabitants 
of informal settlements, life is a shared experience of perpetual lack of basic infrastructure, subtle exploitation by well resourced/connected residents, relentless intimidation of ejection, multifarious land and resource disputes, and a feeling that the settlement's future is not for them (McFarlane and Silver, 2017a; Roy, 2009; Watson, 2009). Consequently, urban residents establish their own forms of selfgovernance, which sometimes usurp government-provided public services, thus contributing to the shaping and re-making of urban infrastructure agendas (Asher and Ojeda, 2009; Gough, 1999; OtengAbabio et al., 2017a; Pilo, 2019).

It is against this backdrop that scholars have interrogated the unequal geographies and experiences of urban service provision and how these can exacerbate informality, inequality and poverty (McFarlane et al., 2017; Pieterse, 2011; Rateau and Choplin, 2021; Roy, 2009, 2011). Focusing on urban Ghana, this article analyses electricity access, highlighting how residents navigate unequal electricity topographies, engage in self-help initiatives, and negotiate informal networks and formal channels of governance practices. We demonstrate how analysing the everyday practices by which marginalized residents navigate the geographies of urban services can provide a more nuanced politics of electricity access that mirrors the complex realities of hybridized forms of governance and the multiple everyday modalities of power that operate to shape urban space in contemporary cities. Consequently, we promote a deeper understanding of how the everyday is a sphere where power is diffuse and relational, and can become commodified through the comercialisation of infrastructure provision.

In many sub-Saharan African (SSA) countries, the demand for electricity exceeds supply resulting in pervasive challenges regarding reliability, quality and affordability (World Bank and International Energy Agency, 2015). Ghana fares rather better than most SSA countries, with around 80 percent of the total population and 90 percent of urban inhabitants reportedly having access to electricity ${ }^{1}$, though as Satterthwaite (2003) has long argued, such figures are based on inaccurate or 'nonsense' statistics, hence overstate access to urban services. Even for households with electricity, the supply can be erratic with frequent blackouts and power rationing that incur costs associated with the disruption of productive activities and damage to equipment (Amankwaa, 2017). A new word 'dumsor' has been added to daily vocabulary in Ghana, which refers to the persistent, irregular and unpredictable electricity outage caused by power supply shortage. Although Ghana committed to universal electricity

\footnotetext{
${ }^{1}$ World Bank, Sustainable Energy for All (SE4ALL) database from the SE4ALL Global Tracking Framework. World Bank, International Energy Agency, and the Energy Sector Management Assistance Program https://data.worldbank.org/indicator/EG.ELC.ACCS.UR.ZS
} 
access by 2020 , it did not have the capacity to meet this target nor ensure that the supply is reliable and affordable? 2 .

This article addresses two core questions: Who are the key actors in informal electricity governance and how do they attain such positions? How do marginalized residents navigate the multiple dimensions of everyday electricity access and what are the consequences for infrastructural governance? The analysis draws on a study conducted in Abuja, an informal settlement in Accra, Ghana, to ascertain how in gaining access to electricity, residents engage in everyday acts of improvisation and negotiate formal and informal domains of governance practices, which often produce uneven power relations. The need to interrogate informality and everyday activities within the production of uneven electricity topographies, in a way that reflects a more diverse set of practices and politics, is emphasized (Silver, 2014).

Two key contributions are made to existing scholarship. First, we inform debates on informality and infrastructural governance, advancing the growing literature that examines informality, infrastructure politics and the making of everyday life in economically marginal urban contexts in the global South (cf. McFarlane and Silver, 2017a, 2017b; Pilo, 2019; Simone, 2010). Second, we provide an illuminating example of the challenges associated with gaining access to electricity in low-income settlements, which tend to overlook the power relations and everyday politics (i.e., the governance, discourses and practices of actors that seek control and access) operating within communities. We argue that informality exists not as an isolated or specific sector of infrastructural service provision but rather as unregulated practices carried out by both state and non-state actors; an informal governance system increases marginality for some while emboldening those with decision-making power. By so doing, we shed light on what 'informal' electricity infrastructure is, how it is made to function, and the complex everyday politics it reflects and reproduces for the urban poor.

The next section presents the theoretical framework for the article, bringing together the concepts of informality, governance and everyday urbanism. The study area and methods used in collecting the data are then outlined. Subsequently, the first empirical section reveals the key actors and associated power relations, through analysing the differentiated practices of electricity provision in Abuja. This is followed by a discussion of the contours of everyday electricity access, which we argue produces

\footnotetext{
${ }^{2}$ For fascinating accounts of the political economy and historical production of Ghana's electricity network see MacLean et al. (2016a, 2016b), Silver (2016) and Adu-Gyamfi et al. (2020).
} 
complex, overlapping, and often dichotomous fields of informal governance practices. The conclusion draws together the key arguments, highlighting our contribution to research on informality and infrastructural governance.

\section{Informality, governance and everyday urbanism}

Conceptual discussions of informality have been ongoing ever since the term was popularised by the ILO in the early 1970s. These have ranged from seeing informality as spatial or economic categories outside formal state control (Hart, 1973; Turner, 1978), to perspectives that seek to move beyond those dichotomies, either by assuming a continuum between informal and formal (Bromley, 1978), or by viewing informality as a mode of regulation (Castells and Portes, 1989). More recently, scholars such as Ananya Roy have claimed that urban informality should be understood as 'a heuristic device that uncovers the ever-shifting urban relationship between the legal and illegal, legitimate and illegitimate, authorized and unauthorized' (Roy, 2011: 233). This viewpoint disconnects informality from underdevelopment, poverty, and illegality, emphasizing its prevalence and shifting quality. In this article we conceive of informality as transcending the domain of state regulation but do not accept a binary understanding that separates informality from formal activities (see Pieterse, 2011). We posit that informality manifests in spheres characterized by disparity between governance domains and actual practice.

The various ways of conceptualizing informality have heightened interest and proved a fertile analytical ground for interrogating and critiquing how it is theorized and governed (Baptista, 2019). In the introduction to a special issue of Urban Studies 'Transcending (in)formal urbanism', Michele et al. (2019) contest how informal urbanism has been conceptualised and argue for a more inclusive theorization that transcends dualisms. Recently, Carrieri et al. (2021) and Sadowski (2021) have contributed to the ongoing debates about power-shifts, tactics and making do, raising questions about who owns the future city and how it should be governed. As Baptista (2019) highlights, states seek to govern informality in a range of ways including through: elimination, such as slum clearance and squatter evictions; disconnection of illegal service connections, often justified by 'othering' narratives of underserving subjects (see Ghertner, 2012); normalization, for example, retrofitting, slum upgrading, land titling, and extension of formal service connections by formalizing contested spaces and activities (see Kamete, 2013); or through toleration, such as mediated and negotiated access to land, housing, basic urban services, work and other rights as a means of sustaining power relations (see Roy and AISayyad, 2004). Informality is governed by strategies that aim to formalize the informal and by 
attempts to perpetuate informality as 'a form of structural power or rationality of government' (Baptista, 2019: 513).

In many low-income urban areas of SSA, informality is widespread and accounts for the greater share of service provision (Amankwaa et al., 2014; Obeng-Odoom, 2013; Oteng-Ababio et al., 2017b). As noted by Simon (2015), in such contexts informality is normal and familiar, not deviant, illegal and unnatural. As both informality and formality traverse through the multiple topographies of city life and infrastructure provision, incorporating informality lays the foundation for inclusive urban governance by closing gaps and delivering services in a resilient, transparent and sustainable manner. Stacey and Lund (2016), for instance, have shown how the provision of basic services by informal institutions influences the workings of formal institutions of government, albeit with the caveat that such relationships often shift back and forth between vilification, tacit acceptance, and productive cooperation. Part of this complex network of governance is an underlying, widely held notion that the absence of government-provided services promotes people's ingenuity whereby they activate their agency and leverage networks beyond their own doorsteps, thus upholding common standards that make life bearable (Perry and Atherton, 2017). In this vein, Zug and Graefe (2014) highlight the dense networks of reciprocity, informal practices, care, debt, gifts and favours, which arise in such situations.

Stacey and Lund's (2016) study of governance in an informal settlement in Accra shows how the forging of an endearing yet enabling social contract in Old Fadama defies conventional conceptualizations of such areas as inherently poor, chaotic, powerless or voiceless. They argue that the structuration of governance is 'enmeshed in and characterized by a distinction between locally produced institutions that sporadically enjoy the power to govern but do not have the legal backing to exercise authority, and the institutions of government with the formal authority to rule but which often lack the power to do so' (Stacey and Lund, 2016: 592). Research has revealed the increasing fluidity and hybridity between informal and formal channels of governance, and how this provides authority and legitimacy for some community actors (cf. Ghertner, 2017; Truelove and Cornea, 2020). For example, a wide variety of heterogeneous infrastructural and governance configurations exist that often go 'beyond the network' and thus require thinking through complex assemblages of political actors and informal institutions (McFarlane and Silver, 2017a; Oteng-Ababio et al., 2017a, b; Truelove, 2019). Such research has called for approaches that bring attention to the scales, domains, and practices of the everyday to gain new insights into the dynamics of power and inequality that permeate urban environments. 
We recognize the plethora of approaches to power, including socio-technical systems as a confluence of social forces and material infrastructure production (see Gaventa, 1980; Rowland and Passoth, 2015), (re)production of state power and control through infrastructure (see Judge, 1995; MacLean et al., 2016b), or powershift frameworks for assessing the politics of sustainability transitions (see Brisbois, 2019; Hess, 2018). Here we approach power through the lens of recent scholarship on the reproduction of control, domination and uneven economic power in 'everyday' relations (Baker et al., 2021; Cornea et at., 2016; Truelove, 2020; Truelove and Cornea, 2020). Our interest in everyday power relations is fundamentally ingrained in the nuanced ways that power works and is mobilized in societies beyond more conventionally conceptualized structural forms and practices of power. By doing so we contribute to discourses on the contested, negotiated and situated nature of everyday urban governance, the multiple ways that politics becomes spatialized, and how power (re)shapes urban infrastructures and spaces in contemporary cities (Truelove and Cornea, 2020). We now turn to everyday urbanism, which in conjunction with urban informality and infrastructural governance, helps us unpack how the multiple modalities of power shape informality and the diverse infrastructural configurations which perpetuate inequality. This further provides an important understanding of how macro structures of power are modified, circumvented and diffused.

Everyday urbanism, which has become a dominant lens through which to research urban life and conceptualize everyday governance, uses a process-oriented analysis to understand how cities work and what drives urban transformation by leveraging the richness of the diverse everyday practices of urban dwellers as the basis for theorization (Alda-Vidal et al., 2018; Truelove and Cornea, 2020). Analyses of access to services emphasize the various everyday practices of service users and the coproduction of hybrid service provision systems, which often run outside, or alongside, the centralized network. While there have been numerous studies on the production, consolidation and contestation of the urban water supply (Peloso and Morinville, 2014; Peloso and Harris, 2017), in recent years electricity has also come into focus. Baptista (2019), Pilo (2019) and Smith (2019) adopt a sociotechnical approach to electricity infrastructure in Maputo, Rio de Janerio, and Kisumu/Kitale respectively, showing how utilities engage with informality to produce access to formal electricity networks through everyday practices of maintenance and repair, landlord-tenant relations and communal meter sharing, which create new kinds of politics. These studies bring a situated approach to everyday urbanism and reveal how urban inequalities are perpetuated not only through the production of infrastructure but through its daily operation, improvisation and governance. 
In this article we bring together informality, governance and everyday urbanism to analyse the everyday practices of informal electricity providers and users to show how most electricity infrastructure is incremental, co-produced, flexible and always in the making. We emphasize the power relations that work to extend and alter the utility, which shape how and to whom electricity is accessible, on whose terms and at what cost. First, however, we present the background to governance and electricity provision in Ghana and the methodology of our study.

\section{Study area and methodology}

The empirical data to address the questions posed in this article are drawn from a study of electricity access in Abuja. Although at the time of the fieldwork Abuja was under the jurisdiction of the Accra Metropolitan Assembly (AMA), AMA has subsequently been fragmented and Abuja now forms part of Korle Klottey Municipal Assembly (KKMA). Municipal Assemblies form part of the local governance system in Ghana, which consists of a four-tier structure: 16 Regional Coordinating Councils (RCCs) on the first tier; six Metropolitan, 56 Municipal and 154 District Assemblies (MMDAs) on the second tier; over 1,300 Urban, Town, Zonal or Area Councils on the third tier; and more than 16,000 Unit Committees on the fourth tier. District Assemblies operate as the basic unit of the local government system and have legislative and executive powers (Kpentey, 2019). Unit Committees have not more than 15 members, of which 10 are elected members and five appointed. Even though they do not have legislative powers, Unit Committees provide a structured mechanism of representation, participation and accountability for their constituents, and work closely with District Assemblies. Both the District Assemblies and Unit Committees face challenges of political and fiscal autonomy (Obeng-Odoom, 2013). Alongside the formal local governance structure, a range of individuals play important roles within communities, including traditional authorities, especially chiefs and elders, community leaders and opinion leaders.

The Electricity Company of Ghana (ECG) is responsible for supplying electricity to all urban communities in southern Ghana. The cost of service connection is borne by consumers. Per ECG's connection policy, a prospective client must obtain an application form at a cost of GH $\phi 10$ (1.7 USD) and return the completed form with several documents for registration: building permit of the premises or a site plan; installation completion certificate signed by a licensed electrician; and proof of identity. Once these have been accepted, a date is fixed for inspection, following which a quotation is prepared for the District Manager to approve and sign. Subject to full payment, a tentative date for the installation is given, officially within three to four weeks, however, this can take more than three months. The upfront payment ranges from $\mathrm{GH} \phi 280-\mathrm{GH} \phi 400$ (48-69 USD) for a single-phased meter, depending on the 
distance from the nearest pole to the property, or from $\mathrm{GH} \phi 2,400$ to $\mathrm{GH} \phi 4,200$ (412-720 USD) where pole extensions are needed. The cost for acquiring a separate meter ranges from $\mathrm{GH} \phi 82-\mathrm{GH} \phi 176$ (1430 USD). The process is not only frustrating and time consuming for customers but costly, since they usually have to pay more than the official charges. As we show below in relation to Abuja, the early settlers living around the Railway Quarters (old site), which is a relatively serviced area, largely have formal electricity connections because they have some form of tenure and pay land rent to the Ghana Railway Corporation (GRC) who in turn pay property rates to the local assembly. Residents in the new site often extend connections from the infrastructure in the old site, which sometimes involves using informal/illegal mechanisms. Thus, unlike formally established settlements, residents in informal settlements use non-state actors to provide electricity despite official policy stipulating that customers shall not: intentionally interfere or knowingly allow interference with the supplier's distribution system or meter; connect supply which is not passed through a meter or tamper with a meter; connect or permit to be connected from the applicant's premises to other premises, without the prior consent of the supplier.

The emphasis here is on Abuja, an informal settlement located in the heart of Accra in a commercial/industrial zone adjacent to Kantamanto market, which is the hub of second-hand clothing in Accra (see Figure 1). Officially Abuja is not recognized as a residential zone due to land tenure issues, making it a contested space in which newcomers to the city can find cheaper sources of housing, connections to kin, and economic opportunities. Until the early 1980s, Abuja was inhabited by workers of the now defunct GRC. Most workers relocated following the company's collapse, with many selling their land titles primarily to Ghanaian migrants who had returned from Abuja in Nigeria after being expelled in 1983, which is how the settlement gained its name. Subsequently Abuja became a popular area due to affordable rent, and proximity to the city centre and central markets that provide incomegenerating opportunities. An estimated 8,000 people live in Abuja, earning their living primarily from business activities, such as second-hand clothing remaking and rebranding, and food vending (Amankwaa, 2016). Abuja hosts a transport terminal and a mix of residential and commercial structures, with many hawkers (street traders) as well as home-based businesses.

Although the state has not provided public services in most parts of Abuja, the early settlers who wield power locally have managed to extend electricity and water supply to the area, resulting in patchwork informal infrastructure. The electricity supply is frequently subject to what is colloquially known as 'light off' or 'dumsor', which is more severe than most other places in Accra due to Abuja's precarious nature. The frequent 'light off', alongside meter overloads (whereby multiple users tap from a single meter) and the use of candles, have contributed to recurrent fire outbreaks, most recently in 2013 and 2015. These 
events have bolstered attempts by city authorities to demolish Abuja. As threats of demolition and eviction continue to cast a long shadow over the settlement's future, construction in Abuja has tended to be small scale, primarily consisting of temporary wooden structures for housing (Amankwaa, 2016).

\section{INSERT FIGURE 1 HERE}

A mixed-methods approach was adopted consisting of a questionnaire survey, semi-structured interviews, focus group discussions and participant observation. Such methodological plurality mimics approaches aimed at generating insights on precarious urban lives through triangulation of data (see Esson et al., 2016; 2020; Gough et al., 2016; Yankson et al., 2017). The research design was implemented in three stages. First, a reconnaissance survey facilitated stratified sampling of residential units into two clusters, one a relatively well-serviced old site (Cluster 1) and the other a less-serviced new site (Cluster 2). Cluster 1 includes the area close to the railway lines and the adjacent police quarters, where early settlers who have titles from GRC live in semi-block and wooden buildings. In contrast, Cluster 2 is located in the central, rapidly developing area with many make-shift wooden structures inhabited by migrants who rent rooms or share space in dormitory-like rooms.

In the second stage, using a systematic sampling technique, every fifth house/structure beginning from a random starting point was selected until a pre-determined sample size of 50 was reached in each cluster (i.e. 100 in total). In addition, four focus group discussions (male youth, female youth, elderly males and elderly females) lasting around 60-90 minutes were conducted with groups of six to eight participants. Six semi-structured indepth interviews, lasting 30-60 minutes, were conducted with Unit Committee members, including an assemblywoman, opinion leader, zongo chief and women's group leader. This representation reflects Ghana's local governance architecture at the community level.

In the final stage, transect walks to map out infrastructure provision, and 'follow-along participant observation' (Finlay and Bowman, 2016) were conducted. All interviews were taped and transcribed verbatim by the authors, where necessary translating from Twi into English. The transcripts were subsequently analysed using NVivo coding to identify categories, themes and trends. The terminologies presented in our analysis emerged from our discussions with participants about their negotiations with the everyday politics of urban life.

\section{Key actors and power relations in electricity provision}


This section focuses on identifying the key actors involved in providing and overseeing the electricity infrastructure in Abuja and how they attain such positions. It highlights how, through self-help initiatives and (in)formal networks, marginalized residents navigate unequal topographies of electricity access.

Residents of Abuja have managed to extend connections from Accra's electricity infrastructure network to part of the settlement through self-help community movements. The early settlers live predominantly in Cluster 1 and have some form of tenancy agreement with GRC. In close collaboration with the assemblyman/woman and Unit Committee members, the early settlers came together in the 1990s to buy electricity poles and cables to provide electricity to the area, including extending supply to Cluster 2 , the rapidly developing area. In order to gain access to this electricity supply, residents had to pay an amount to a community leader, which was set aside to buy electric cables for future extensions, maintenance and upgrades. Thus, in Abuja Old Site (Cluster 1) there is an electricity transformer, transmission poles and lines, and residents generally use rechargeable lamps. In the New Site (Cluster 2), where electricity was subsequently extended, the few meters have multiple connections and many households cope by relying on candles, torches, kerosene lamps, and at times private generators to power their businesses.

This form of electricity infrastructure connection 'from below', involving leveraging different actors and networks as well as formal and informal institutions, results in residents of Abuja becoming connected to electricity in a splintered fashion (Coutard, 2008; Dawson, 2021), with many uncertainties and negotiations occurring outside the watch of the meter provider/owner. The questionnaire survey showed that only 17 percent of households (primarily in Cluster 1) have their own separate connection, with just over half (54 percent from both clusters) accessing electricity via a shared house/shop metered connection. Of the remaining households, 20 percent tap power from a neighbour outside their residence/shop, while 9 percent have no connection resorting to alternative sources of lighting. These multiple modalities of electricity connection reflect the hybrid arrangements that emerge between and across actors, and the different negotiations that operate to shape the electricity infrastructure. Two key power governance actors emerged in this process, namely, 'power-owners' and 'power-agents'.

Power-owners are individuals who have managed to claim ownership of the electricity infrastructure through established relationships with the Electricity Company of Ghana (ECG). Their power stems from determining who connects to the main transmission line, for what purpose and the cost of the connection. They are mostly middle-aged men and women who have occupancy permits ${ }^{3}$ from GRC or early settlers who became landlords after relocating elsewhere but still pay rent to GRC. Due to their

\footnotetext{
${ }^{3}$ An occupancy permit is the tenancy agreement between a resident and GRC.
} 
status as long-time owners and well resourced/connected residents, they wield influence and use their connections with people in authority to acquire separate metered connections. Power-agents act as intermediaries to aid individuals secure connections to the transmission lines from the power-owners and help acquire private meters from ECG to connect and sell power to other residents. They are primarily mid-to-late settlers who have secured residential and/or working spaces from the early settlers. The power-agents can be portrayed as opportunistic residents who, through family ties, community-based group affiliations, successful business activities and political connections, have managed to build up social capital within and outside the settlement.

Power-owners and their power-agents have taken on a broader community role beyond mediating access to meters/connections, including liaising selectively with the local authority, the electricity provider, and initiating and navigating many facets of community governance. Consequently, the terms 'power-owners' and 'power-agents', at times used by residents themselves, refer to their superior tenure position and, more importantly, their disproportionate power in relation to electricity provision. While the power-owners act as gatekeepers to the physical infrastructure, the power-agents serve as overseers in charge of everyday negotiations and the politics of electricity access at the household and business level, regarding who accesses power, on what terms, at what cost and for how long. The power-owners have more power, however, because they determine the number of power-agents who can connect to the main electricity grid. The roles of power-owners and power-agents, however, does not in any way imply that the official service provider ECG has ceded, or even tacitly accepted, ownership of part of the distribution network to community members.

Power-owners are expected to oversee the activities of power-agents to avoid transmission overload but the relationship can be tricky as most power-agents clandestinely install additional meters over and above the 'official' ones. This allows them to serve many more residents under the cover of goodneighbourliness, even though this is not done without monetary motivations. The quote below from a power agent describes how they connect to the grid and sell power to residents:

If you are free [have good contacts] with the top people, I mean Assemblywoman or Alhaji [unit committee member] then it's easy to get a meter or be connected to one. They will call the ECG official to come and inspect your premises. After you've paid they'll fix a date for the meter installation. Usually it takes 6 months but if you're lucky then 3 months. ... Once you get connected, people will start coming to you for power. So we charge them connection fee then ask our local electricians here to do the extension work after they've bought the cable and paid workmanship. (Male participant, elderly focus group)

This presentation of the key actors involved in electricity supply in Abuja shows the multiple scales at which the provision of electricity infrastructures is determined. Both the power-owners and power- 
agents have to negotiate formal channels and leverage informal networks, including the District Assembly, service provider (ECG), community leaders, electricians and prepaid vendors, to gain access to the electricity distribution network and meter connections. This illustrates the diverse practices of urban-dwellers who must intervene to acquire, make and re-make critical infrastructures through mutual improvisation and local political arrangements (McFarlane, 2018; Roy, 2009). Non-state actors thus not only influence the state's informal decision-making practices regarding electricity infrastructure but also exert power over on-the-ground electricity provisioning, revealing their influence on both the state and localized forms of everyday electricity politics (Truelove and Cornea, 2020).

The analysis further shows how strategies to access services are being created and manipulated by well resourced/connected residents (Amankwaa, 2016; McFarlane et al., 2017), preventing less powerful newcomers from gaining their own connection. With the rising number of tenant households in Accra (Appeaning Addo, 2016), landlords have the autonomy to decide whether to allow a private meter installation in their residence. Their decision is partly fuelled by the profit they can make using the shared system, whereby the bill is collectively paid by tenants resulting in free electricity for themselves. There is also an economic disincentive for tenants to have separate meters due to precarious tenancy arrangements characterised by short notice evictions at the landlord's discretion. A young man who resides with a friend in a container shop ${ }^{4}$ explained how:

These days it's not easy to get a room and your money is so little you don't dare to get a meter. Even if you do, the process is too long. Everyone wants money and who are you to tell the landlord or the friend you are perching [residing] with that you want to get your own meter, or ask him to show you the bill before paying? You must have secured a new room to do that because he will eject you at the slightest provocation. (Male participant, youth focus group)

The politicisation and commercialisation of the electricity infrastructure, therefore, consigns residents to the mercy of power-owners and power-agents. Residents who resort to tapping power from a neighbour outside their dwelling negotiate with the meter owner/user and contribute to the purchasing of prepaid credit. One resident who runs a shop shared her frustration at having to navigate multiple terrains to access electricity amid manipulation, intermittent supply, high cost and exploitation:

The neighbours around refused to help so I had to extend power from an in-law's line at the other end. Not only was the cable cost high, I suffer power cuts anytime there is a strong wind or downpour as the electrician joined pieces of wires together. ... The 'dumsor' [light off] is too much and the current is always low. Too many people are on the line. At my husband's drinking

\footnotetext{
${ }^{4} \mathrm{~A}$ container shop is a metallic container used for doing business.
} 
bar, where he taps from a line nearby, the owner collects money every other day to buy prepaid credit. We know he cheats us but what can we do? (Female participant, elderly focus group)

Residents with no form of electricity access, who are usually caretakers 5 for relatives (see Gough and Yankson, 2011), use candles for light, which poses a major concern as this is believed to be the main cause of fire outbreaks. A shower operator whose business suffered from one such fire incidence recounted how:

The wooden structures and candles are the main causes of fire. Because of eviction fears people do not build block houses. So when there is fire it spreads fast. We caution residents about candle use but some are just careless. The recent one [fire] was caused by a young girl. ... A lot of structures were destroyed and properties lost. (Male participant, elderly focus group)

While power-owners and power-agents enjoy access and control, and commodify the infrastructure network, the politicization of electricity reproduces inequalities that leave most residents dependent on patchy power supply. Such unequal electricity topographies are maintained and regulated by powerowners and power-agents, who reinforce structures that configure everyday politics of 'making do' and reproduce relations and networks, thereby making inequality structural and diffuse.

Several key functions enable power-owners and power-agents to collectively establish themselves as 'power governance actors': they take an increasingly prominent role in informal processes of mediating and governing electricity access, thus embodying and producing uneven power relations. For example, they negotiate (in)formal channels/networks to install meters, follow up on complaints of faulty meters, settle disagreements over rental and utility payments, and help newcomers settle in. They also liaise with the fire service to ensure unsafe structures are demolished after fire outbreaks, caution people on candle use, identify fire hazards including meter overloads and exposed wiring, and look out for new structures that block pathways. In a recent development, the power-owners and power-agents are leading initiatives to erect a new transmission pole in Cluster 2 to cater to the needs of households and businesses in order to tackle transmission overload, which contributes to the frequent fire outbreaks and power outages. This action has been spurred by the refusal of the city authority, Accra Metropolitan Assembly (AMA), and the Ghana National Fire Service (GNFS) to officially reconnect the settlement to the electricity grid after a shutdown of the electricity transformer following the 2015 fire. Despite AMA's policy of not extending basic services to settlements without legal status or ones earmarked for demolition, through negotiations and informal arrangements the community leaders, power-owners and

\footnotetext{
${ }^{5} \mathrm{~A}$ caretaker is a custodian who takes care of a property on behalf of others.
} 
power-agents, and other resourceful residents have succeeded in persuading ECG officials to install meters, fix major electrical faults, and inform GNFS if fire breaks out.

The above analysis has revealed how community movements, everyday acts of improvisation, and incremental changes by marginalized residents to obtain essential services, even if they are illegal and temporary, cannot function without the support of the municipal authority. State and non-state actors engage in a range of everyday practices that reproduce their role as legitimate governance actors. Such efforts by influential residents reflect emerging forms of self-made institutions in informal settlements, which endeavour to implement rules that reproduce urban politics and local governance practices (Fischer et al., 2017; Ghertner, 2017). Negotiating access has varied and situated outcomes on residents and state/non-state actors, worsening marginality for some, while emboldening others with increased access and decision-making power (Cornea et al., 2016; Pilo, 2019). In her analysis of electricity in the favelas of Rio de Janeiro, Pilo (2019) shows how networked inequalities emerge within the grid through a plurality of governance actors; everyday negotiations that surround the electricity infrastructure reveal differing rationalities at play, as well as produce new kinds of politics.

Based on the foregoing analysis, we perceive governance as 'strategic actions' or interventions that address specific challenges in urban spaces and the institutional frameworks and actors that support them. Everyday governance approaches focus on the interplay between actors and processes which construct spheres as problematic and the day-to-day practices of actors who endeavour to intervene in these spheres. Here, we distinguish between two facets: mediation of everyday practices by 'powerowners' and 'power-agents' (such as, making connections, purchasing credit, forming payment schemes, and negotiating with the electricity company) and the strategic steering of the community, whereby the mediators' role has been extended into influencing and creating new and hybrid channels of governance (including managing distribution extensions). We now turn to discuss these dimensions by exploring how the existing system of electricity provision in Abuja influences the everyday dynamics of electricity access and reproduces informal governance practices.

\section{Everyday contours of electricity access and governance practices}

This section focuses on the diverse practices and wider ways in which urban residents manage and navigate the electricity terrain in their everyday life. It first highlights the everyday contours and politics of electricity access and then illustrates how this produces the complex realities of hybridized modalities of governance. Specifically, we interrogate important hybrid arrangements and decisions which have to be made, such as: Where do the meters used by the power-owners and power-agents come from? 
Who installs the meters, connects to the grid, and fixes faults? How do residents get credit on the meters and who do they pay top-up or their bills to? How do residents navigate the everyday politics of power-owners and power-agents and circumvent or offset their exploitation, as well as sustain relationships with them?

The complex everyday governance regimes and social infrastructures are established through the prominent roles played by community leaders, power-owners and power-agents, and well-connected residents and landlords, who collectively can be referred to as a 'community movement'. By lobbying government officials, the spatial electricity infrastructure is sustained by the community through an interface of relational practices and everyday politics. The time and work that the community movement puts into creating and sustaining social infrastructures of electricity access are a form of investment in themselves, and part of a wider reciprocity that is at once economic and political.

\section{Economic dimensions of access}

Reciprocal exchanges form the basis of economic life through which people connect, extend, credit, buy or sell electricity between themselves. At the household level, residents deploy their agency and leverage networks to manoeuvre discernible inequalities and everyday micro-politics surrounding electricity infrastructure. For example, residents who obtain connections in turn allow others to connect to their source through the 'back door', usually to offset connection costs or reciprocate kind gestures. The quote below from an influential opinion leader sheds light on these nuances and how residents take advantage of the situation to make profit:

When I needed power, I went to a [power] agent to help me. He couldn't refuse because I am a Field Officer at the Water Works Department and I help people around with their water issues. My wife even helped his son gain admission into high school where she is a matron. ... Once you are connected you make money because people will come to you. It is like water, it is an everyday issue so those who own structures or shops and have meters are really making good money. Here is a business place and we all need electricity in one way or the other. (Male participant, elderly focus group)

These arrangements create a network of clandestine connections, outside the watch of power-agents, which can extend to as many as ten users pirating from one meter source. Such everyday transactions require meter owners, who allow other users to connect, to constantly monitor the supply network to check for meter overloads and 'illegal' extensions, and ensure that users pay regularly. Beyond the everyday navigations, such individuals have to strategically negotiate with the power-agents or residents who have facilitated their electricity connection to sustain their supply. Such hybrid arrangements produce unequal experiences of the power relations that shape everyday infrastructural 
governance. For example, existing users can negotiate with power-agents and individuals to deny access to potential users who ply the same trade, or lobby for persons from their ethnic group to get connected. This supports claims that in informal settlements access to services is always politicised and reflects dominant relations of class, gender, and ethnicity (McFarlane, 2018).

In the business environment, where new operators have led to a burgeoning demand for electricity, electricity infrastructures are created and reproduced in even more dynamic ways as business owners often make multiple arrangements and leverage networks that (re)produce unequal topographies and experiences of access. Especially among young people establishing a business for the first time, a group of friends will typically pool resources and networks; one person negotiates to obtain the workspace, another uses their membership of community-based associations to get electricity, and others pay the bills. When meters are shared, cost sharing is always an issue. The comment below by a resident who is connected to a power-agent and sells power to other residents highlights the complexities, uncertainties and vigilance associated with the shared system and the payment modalities:

You first sort out the connection fee with the owner of the line. Then you contribute to buy the prepaid credit or pay in turns. We gauge how many units we consume in a week so in case someone uses additional gadgets or another person joins the line we can detect it. You pay like 30 cedis [8.6 USD] a week ... If you default payment for two times you will be disconnected so those who can't pay on time always negotiate with their neighbours. Others also access power on a daily basis so on the days they don't have money or need light they get disconnected. (Female participant, elderly focus group)

As this account highlights, access to power is incremental, sporadic and highly dependent on the ability to pay regularly, navigate the multiple arrangements and excessive demands of power-agents and individual suppliers, and endure manipulations, disappointments and exploitation. The issue of exploitation emerged as a common concern for both residents and business operators as they normally pay a flat rate or amount that is several times higher than what they actually consume. To manage this, users strategically position themselves to negotiate the different arrangements that exist between and across these different power-actors. Other users change their meter or connection source but this has to be done with extreme care and tactic, as highlighted by a 31-year-old male participant during the youth focus group discussion:

Those doing the electricity business take advantage of us but when it becomes too much then we change the supplier. But it's not every supplier you can easily change because some own 
and control several meters and are highly connected so if you are not careful they can secretly conspire against you.

Electricity access is thus a manifestation of everyday politics, power relations, and the perpetuation of inequality as residents try to access, negotiate and modify the power-owners' and power-agents' supply system. These findings resonate with Truelove's (2020) work on water provision in Delhi's informal settlements, where residents come to comprehend local governance actors' 'infrastructural power' over critical urban resources as being beyond a clear formal/informal and state/non-state divide. As her research illustrates, residents negotiate with both state and non-state actors, while these same governance actors strategically pivot between state and non-state identities and responsibilities to gain further power in controlling water infrastructures. We turn to discuss these dimensions in the next section.

\section{Political/governance dimensions of access}

Reciprocal exchanges form the basis of political authority and informal governance through which well resourced/powerful residents, power-owners and power-agents, and community leaders compete and cooperate, agree and disagree, build trust and compromise with city authorities. Their influence is especially demonstrated during threats of eviction and internal tensions and conflicts. In exchange for these leadership commitments and services, power-owners and power-agents, as well as community leaders, enjoy residents' recognition in numerous reciprocal ways, which shape the social contract. Residents show their approval and support by observing the local authority's rules and guidance including: securing a living and working space, accessing basic infrastructure and services, joining community-based associations (workers' union or ethnic groups) and ensuring personal security. The quote below from a female Unit Committee member, who resides in Abuja, gives a picture of how such social contracts are established:

The aftermath of the recent fire incidence led to fear and suspicion of eviction threats from city authorities and reconnection to the electricity mains. We finally petitioned our constituency MP who agreed to contact the Accra Mayor on our behalf. He promised to forward electricity poles, which, together with a transformer and electricity meters, were welcomed by residents. Their instalment will reduce fire risk and improve residents' sense of security. ... City officials acknowledge our right of residence, [it is] only that there are no formal establishments between us.

In this way, the community movement derives legitimacy locally by demonstrating its ability to encounter and negotiate with the District Assembly and city officials to acquire facilities (for example, meters and transmission poles), offer services (such as meter installation and prepaid vendor points), 
fix faulty transformers, and conduct fire safety audits. Through informal negotiations, residents are able to establish rights and social contracts that underpin and define what constitutes ideas of everyday infrastructural governance and informality through the institution of their own local authority and system of electricity provision. Informal governance arrangements, everyday acts of improvisation, and incremental modifications lead to the provision of basic services by marginalised residents, thereby influencing the workings of formal institutions of government, such as AMA, ECG and GNFS, through installing the electricity infrastructure, fixing major faults and general maintainance. Informality is thus central to understanding how the urban poor negotiate complex governance networks and navigate differing pathways of everyday access to the electricity infrastructure.

The contours of electricity access thus create spheres of everyday governance regimes at different levels. The masses depend on the power governance actors to access services in their everyday life and confirm the rulership of influential residents by yielding to their authority. Those who wield influence and claim ownership over resources establish their local power/authority from relations with statutory authorities. In this sense, the topography of infrastructure provision in Abuja can be portrayed as an arena of informal mechanisms that legitimize both formal political institutions and self-made institutions (Paller, 2014). Service provision, therefore, involves a reciprocal dynamic that is central to the production of rights and authority between the masses and state/non-state actors (Stacey and Lund, 2016). This scenario resonates with how governance practices emerge through everyday navigations of claims to services in return for obligations. Rather than dichotomous (state/non-state, formal/informal) approaches to understanding informality and everyday urban governance, as Truelove and Cornea (2020) highlight, there are complex, overlapping, and often contradictory arenas of power that inform a wider understanding of what studies of governance in the everyday should incorporate. Analyzing urban infrastructures and their everyday governance is primarily useful for considering micro-politics, power relations and the (re)production of inequality because such infrastructures are both the material expression, and often the means of transforming and shaping unequal access to services (Truelove and Cornea, 2020).

\section{Conclusion}

This article provides a nuanced understanding of everyday politics and experiences of inequality, bringing a situated approach to infrastructural governance, with particular emphasis on local institutions, diverse infrastructural configurations and multi-scalar power relations. Formal and informal processes converge to (re)configure electricity geographies and governance practices, primarily through the agency of power-owners, power-agents and community leaders, who operate mainly 
outside, or on the margins, of where state institutions function. Two key findings have emerged. First, through community movements, everyday acts of improvisation and incremental changes, marginalised residents' access to electricity has improved. The spatiality of the electricity infrastructure, however, has created inequity and opportunities for exploitation by power-owners and power-agents to control the distribution network and, in turn, privately supply/sell power. Second, the contours of electricity access have revealed residents' constant navigation of the electricity infrastructure. We have shown how electricity is sometimes accessed on the basis of monetary exchange but also through favours and perceived reciprocal exchanges, thereby producing everyday politics of 'making do'. Such spatial and social contours perpetuate everyday micro-politics and reflect how electricity connections are negotiated, access is monetized, and illegality is excused on grounds of good-neighbourliness.

These manifestations reveal the contested, negotiated and situated nature of everyday infrastructural governance, the multiple ways that politics become spatialized, and how power shapes the unequal geographies of infrastructures (Truelove and Cornea, 2020). Understandings of the everyday governance of contemporary cities must take into account actors, practices and processes that have too often been overlooked by scholars: the power-owners and power-agents who shape patterns of inequality within the network and who act for the state and outside of the state at different points in time, as well as the informal authority that regulates between residents and city officials (cf. Kundu and Chatterjee, 2020; Pilo, 2019). This links to a fundamental conundrum in the discourse on informality in African cities - states' reluctance to engage with residents' experiences, concerns and expectations an issue that has been compellingly interrogated in ongoing debates in Urban Studies (see Carrieri et al., 2021; Sadowski, 2021). The case of Abuja has illustrated how residents collaborate with the state to provide the type of service and support that individual and collective efforts cannot. The situation is complicated by the conflicting roles of the state: AMA is planning to evict and demolish parts of Abuja, while at the same time officials are providing essential infrastructure, such as electricity transformers and meters. These complexities underscore how the state is dialectical, operating in the shadows and creating hybrid governance regimes, which reproduce uncertainty regarding the settlement's future (see Cobbinah and Darkwah, 2017; Sadowski, 2021).

Informality has been shown to be both a 'designation' that helps in understanding governance and a 'broader logic' that traverses dichotomous boundaries (Roy, 2011; Watson, 2003). Our article advances these notions by highlighting that far from being a domain of regularized practice, informality manifests in spheres marked by disparity between governance domains and actual practice. Informality is thus understood to be heterogeneous and (re)produced through power relations and everyday 
performances, which lead to an unintended transferal of ordinary tasks of government to informal institutions. The everyday contours of electricity access reflect the (in)ability of different institutions to govern, emphasizing how the governance field is fluid and hybrid, and is not controlled exclusively by any one actor. Consequently, a focus on formal institutions alone will not provide adequate insight into actual governance or the realities of urban life (see Acheampong and Ibrahim, 2016; Watson, 2009).

As shown here, the multiple modalities of power that shape informality and perpetuate inequality are important for understanding how macro structures of power are modified, circumvented and diffused (cf. Cornea, 2020; Merrifield, 2012). Marginalized residents not only access electricity through formal domains and in collaboration with state actors, but also through long-standing everyday tactics and practices that blur and operate outside the realm of the state. Paying critical attention to everyday practices and politics illuminates the ways community actors, informal authorities, and a multiplicity of other key intermediaries assume state-like authority and roles, fashioning not only the governance of key urban infrastructures but how marginalized residents legitimize long-term claims and rights in the city outside direct engagements with the state (Truelove and Cornea, 2020). Given that mobilisations to improve equity become manifested through the politics of breakdown, maintenance, and inadequacy of infrastructure access, informality should be consciously incorporated into progressive urban energy politics in order to promote inclusive and affordable energy for all (cf. Obeng-Odoom, 2013; Watson, 2009). In this sense, informality should be seen not as a victim of urbanization but as heterogeneously inherent to the urbanization process. Informality does not constitute failure or backwardness but a sphere of opportunity, innovation and transition.

\section{References}

Acheampong RA and Ibrahim A (2016) One nation, two planning systems? Spatial planning and multilevel policy integration in Ghana: Mechanisms, challenges and the way forward. Urban Forum 27: 1-18.

Adu-Gyamfi S, Amakye-Boateng K, Awuah D, Oware R and Quansah S (2020) An evolutionary study of production of electricity in Ghana (1900-1960s). History of Science and Technology 10(1). DOI:

https://doi.org/10.32703/2415-7422-2020-10-1(16)-10-33

Alda-Vidal C, Kooy M and Rusca M (2018) Mapping operation and maintenance: an everyday urbanism analysis of inequalities within piped water supply in Lilongwe, Malawi. Urban Geography 39(1): 104-121

Amankwaa EF (2016) Poverty penalty: strategies for coping with water access problems among urban poor in Abuja, Accra. In: Shaw RJ (ed). Ensuring availability and sustainable management of water and sanitation for all: Proceedings of the 39th WEDC International Conference, Kumasi, Ghana, 11-15 July 2016, pp. 1-6. Refereed paper 2555. WEDC: Loughborough University.

https://repository.Iboro.ac.uk/articles/conference_contribution/Poverty_penalty_strategies_for_coping_w ith_water_access_problems_among_urban_poor_in_Abuja_Accra/9594629 
Amankwaa EF (2017) Water and electricity access for home-based enterprises and poverty reduction in the Greater Accra Metropolitan Area (GAMA), Ghana. PhD Thesis, University of Ghana.

Amankwaa EF, Owusu AB, Owusu G and Eshun F (2014) Accra's poverty trap: Analysing water provision in urban Ghana. Journal of Social Science for Policy Implications 2(2): 69-89.

Appeaning Addo I (2016) Assessing residential satisfaction among low income households in multihabited dwellings in selected low income communities in Accra. Urban Studies 53(4): 631-650.

Asher $\mathrm{K}$ and Ojeda D (2009) Producing nature and making the state: Ordenamiento territorial in the Pacific lowlands of Colombia. Geoforum 40: 292-302

Baker L, Hook A and Sovacool BK (2021) Power struggles: Governing renewable electricity in a time of technological disruption. Geoforum 118: 93-105

Baptista I (2019) Electricity services always in the making: Informality and the work of infrastructure maintenance and repair in an African city. Urban Studies 56(3): 510-525

Brisbois MC (2019) Powershifts: A framework for assessing the growing impact of decentralized ownership of energy transitions on political decision-making. Energy Research \& Social Science 50: 151-161.

Bromley R (1978) Introduction - The urban informal sector: Why is it worth discussing? World Development 6(9-10): 1031-1198.

Carrieri AP, Papadopoulos D, Quaresma EA and da Silva ARL (2021) The ontology of resistance: Power, tactics and making do in the Vila Rubim market. Urban Studies 58(8): 1615-1633

Castells M and Portes A (1989) World underneath: The origins, dynamics, and effects of the informal economy. In: Portes A, Castells M and Benton LA (eds) The Informal Economy: Studies in Advanced and Less Developed Countries. Baltimore, MD: The Johns Hopkins University Press, pp. 11-37.

Cobbinah PB and Darkwah RM (2017) Urban planning and politics in Ghana. GeoJournal 82: 12291245.

Cornea N (2020) Territorialising control in urban West Bengal: Social clubs and everyday governance in the spaces between state and party. Environment and Planning C: Politics and Space 38(2): 312-328.

Cornea N, Zimmer A and Veron R (2016) Ponds, power and institutions: The everyday governance of accessing urban water bodies in a small Bengali city. International Journal of Urban and Regional Research 40(2): 395-409.

Coutard O (2008) Placing splintering urbanism: Introduction. Geoforum 39(6): 1815-1820.

Dawson K (2021) Under the wire. Splintered time and ongoing temporariness in Accra's electropolis. City, doi: 10.1080/13604813.2021.1885903

Esson J, Amankwaa EF and Mensah P (2020) Boys are tired! youth, urban struggles, and retaliatory patriarchy. Transactions of the Institute of British Geographers 43: 184-199. 
Esson J, Gough KV, Simon D, Amankwaa EF, Ninot O and Yankson PWK (2016) Livelihoods in motion: Linking transport, mobility and income-generating activities. Journal of Transport Geography 55: 182188.

Finlay JM and Bowman JA (2016) Geographies on the move: A practical and theoretical approach to the mobile interview. The Professional Geographer 69(2): 263-274.

Fischer A, Holstead K, Hendrickson CY, et al. (2017) Community-led initiatives' everyday politics for sustainability - Conflicting rationalities and aspirations for change? Environment and Planning A 49(9): 1986-2006.

Gaventa J (1980) Power and Powerlessness. Urbana: University of Illinois Press.

Ghertner DA (2012) Nuisance talk and the propriety of property: Middle class discourses of a slum-free Delhi. Antipode 44(4): 1161-1187.

Ghertner DA (2017) When is the state? Topology, temporality, and the navigation of everyday state space in Delhi. Annals of the American Association of Geographers 107(3): 731-750.

Gough KV (1999) The changing nature of urban governance in peri-urban Accra, Ghana. Third World Planning Review 21(4): 397-414.

Gough KV, Chigunta F and Langevang T (2016) Expanding the scales and domains of insecurity: Youth employment in urban Zambia. Environment and Planning A 48: 348-366.

Gough KV and Yankson PWK (2011) A neglected aspect of the housing market: The caretakers of periurban Accra, Ghana. Urban Studies 48(4): 793-810.

Hart K (1973) Informal income opportunities and urban employment in Ghana. The Journal of Modern African Studies 11(1): 61-89.

Hess DJ (2018) Energy democracy and social movements: A multi-coalition perspective on the politics of sustainability transitions. Energy Research \& Social Science 40: 177-189.

Judge D (1995) Understanding Urban Power. In: Judge D, Stoker G and Wolman H (eds) Theories of urban politics. Thousand Oaks, CA: Sage.

Kamete AY (2013) Missing the point? Urban planning and the normalisation of 'pathological' spaces in southern Africa. Transactions of the Institute of British Geographers 38(4): 639-651.

Kpentey S (2019) Local government and participation in Ghana. Academic Review of Humanities and Social Sciences 2(2):168-188.

Kundu R and Chatterjee S (2020) Pipe dreams? Practices of everyday governance of heterogeneous configurations of water supply in Baruipur, a small town in India. Environment and Planning C: Politics and Space. DOI: https://doi.org/10.1177\%2F2399654420958027

MacLean LM, Bob-Millar GM, Baldwin E and Dickey E (2016a) The construction of citizenship and the public provision of electricity during the 2014 World Cup in Ghana. Journal of Modern African Studies 54(4): 555-590 
MacLean LM, Gore C, Brass JN, et al. (2016b) Expectations of power: the politics of state-building and access to electricity provision in Ghana and Uganda. Journal of African Political Economy and Development 1: 103-134.

McFarlane C (2018) Fragment urbanism: Politics at the margins of the city. Environment and Planning D: Society and Space 36(6): 1007-1025.

McFarlane C and Silver J (2017a) Navigating the city: dialectics of everyday urbanism. Transactions of the Institute of British Geographers 42(3): 458-471

McFarlane C and Silver J (2017b) The poolitical city: "Seeing sanitation" and making the urban political in Cape Town. Antipode 49(1): 125-148.

McFarlane C, Silver J and Truelove Y (2017) Cities within cities: Intra urban comparison of infrastructure in Mumbai, Delhi and Cape Town. Urban Geography 38: 1393-1417.

Merrifield A (2012) The politics of the encounter and the urbanization of the world. City 16: 269-283.

Michele A, Cecilia D and Colin M (2019) Special Issue: Transcending (in)formal urbanism. Urban Studies 56(3): 475-487.

Obeng-Odoom F (2013) Governance for Pro-poor Urban Development: Lessons from Ghana (1st edition). London: Routledge.

Oteng-Ababio M, Smout I, Amankwaa EF and Esson J (2017b) The divergence between acceptability of municipal services and urbanization in developing countries: Insights from Accra and SekondiTakoradi, Ghana. Geografisk Tidsskrift-Danish Journal of Geography 117(2): 142-154.

Oteng-Ababio M, Smout I and Yankson PWK (2017a) Poverty politics and governance of potable water services: The core-periphery syntax in Metropolitan Accra, Ghana. Urban Forum 28(2): 185-203.

Paller JW (2014) Informal institutions and personal rule in urban Ghana. African Studies Review 57(3): 123-142.

Peloso MM and Harris LM (2017) Pathways for participatory water governance in Ashaiman, Ghana: Learning from institutional bricolage and hydrosocial perspectives. Society \& Natural Resources 30(12): 1491-1506.

Peloso M and Morinville C (2014) 'Chasing for water': Everyday practices of water access in peri-urban Ashaiman, Ghana. Water Alternatives 7(1): 121-139.

Perry B and Atherton M (2017) Beyond critique: the value of co-production in realising just cities? Local Environment 22(3): 1-16

Pieterse E (2011) Grasping the unknowable: coming to grips with African urbanisms. Social Dynamics 38(1): 5-23.

Pilo F (2019) Negotiating networked infrastructural inequalities: Governance, electricity access, and space in Rio de Janeiro. Environment and Planning C: Politics and Space. DOI:

https://doi.org/10.1177\%2F2399654419861110 
Rateau M and Choplin A (2021) Electrifying urban Africa: energy, access, city-making and globalization in Nigeria and Benin. International Development Planning Review doi.org/10.3828/idpr.2021.4

Rowland NJ and Passoth J-H (2015) Infrastructure and the state in science and technology studies. Social Studies of Science 45(1): 137-145

Roy A (2009) Why India cannot plan Its cities: Informality, insurgence and the idiom of urbanization. Planning Theory 8: 76-87.

Roy A (2011) Slumdog cities: Rethinking subaltern urbanism. International Journal of Urban and Regional Research 35(2): 223-238.

Roy A and AlSayyad N (eds) (2004) Urban Informality: Transnational Perspectives from the Middle East, Latin America, and South Asia. Lanham, MD: Lexington Books.

Sadowski J (2021) Who owns the future city? Phases of technological urbanism and shifts in sovereignty. Urban Studies 58(8): 1732-1744

Satterthwaite D (2003) The Millennium Development Goals and urban poverty reduction: great expectations and nonsense statistics. Environment and Urbanization 15(2): 181-190.

Silver J (2014) Incremental infrastructures: Material improvisation and social collaboration across postcolonial Accra. Urban Geography 35(6): 788-804.

Silver J (2016) Disrupted infrastructures: an urban political ecology of interrupted electricity in Accra. International Journal of Urban and Regional Research 39(5): 984-1003

Simon D (2015) Uncertain times, contested resources: Discursive practices and lived realities in African urban environments. City 19: 216-238.

Simone A (2010) City Life from Dakar to Jakarta. Routledge: New York.

Smith S (2019) Hybrid networks, everyday life and social control: Electricity access in urban Kenya. Urban Studies 56(6): 1250-1266.

Stacey P and Lund C (2016) In a state of slum: Governance in an informal urban settlement in Ghana. Journal of Modern African Studies 54(4): 591-615.

Truelove Y (2019) Gray zones: The everyday practices and governance of water beyond the network. Annals of the American Association of Geographers 109(6): 1758-1774.

Truelove $Y(2020)$ Who is the state? Infrastructural power and everyday water governance in Delhi. Environment and Planning C: Politics and Space. DOI: https://doi.org/10.1177\%2F2399654419897922

Truelove $Y$ and Cornea N (2020) Rethinking urban environmental and infrastructural governance in the everyday: Perspectives from and of the global South. Environment and Planning C: Politics and Space DOI: https://doi.org/10.1177\%2F2399654420972117

Turner JFC (1978) Housing in three dimensions: Terms of reference for the housing question redefined. World Development 6(9-10): 1135-1145. 
Watson V (2003) Conflicting rationalities: implications for planning theory and ethics. Planning Theory and Practice 4: 395-408.

Watson V (2009) The planned city sweeps the poor away...: urban planning and 21st century urbanization. Progress in Planning 72: 151-193.

World Bank and International Energy Agency (2015) Sustainable Energy for All 2015: Progress Toward Sustainable Energy. Washington, DC: World Bank.

https://openknowledge.worldbank.org/handle/10986/22148

Yankson PWK, Gough KV, Esson J and Amankwaa EF (2017) Spatial and social transformations in a secondary city: The role of mobility in Sekondi-Takoradi, Ghana. Geografisk Tidsskrift-Danish Journal of Geography 117(2): 82-92.

Zug S and Graefe O (2014) The gift of water: Social redistribution of water among neighbours in Khartoum. Water Alternatives 7(1): 140-159. 